\title{
Soil management systems and their effect on the weed seed bank
}

\author{
Cesar Tiago Forte ${ }^{(1)}$, Leandro Galon ${ }^{(1)}$, Amauri Nelson Beutler(2), Felipe José Menin Basso(1), \\ Felipe Nonemacher ${ }^{(1)}$, Francisco Wilson Reichert Júnior ${ }^{(1)}$, Gismael Francisco Perin ${ }^{(1)}$ and Siumar Pedro Tironi( ${ }^{(3)}$ \\ (1)Universidade Federal da Fronteira Sul, Campus Erechim, ERS 135, Km 72, № 200, Caixa Postal 764, CEP $99700-970$ Erechim, RS, \\ Brazil. E-mail: cesartiagoforte@hotmail.com, leandro.galon@uffs.edu.br, bepifelipe@gmail.com, felipe.nonemacher@hotmail.com, \\ chicowrj@gmail.com, gismaelperin@gmail.com (2)Universidade Federal do Pampa, Campus Itaqui, Rua Luiz Joaquim de Sá Britto, \\ s/no, Promorar, CEP 97650-000 Itaqui, RS, Brazil. E-mail: amaurib@yahoo.com.br ${ }^{(3)}$ Universidade Federal da Fronteira Sul, Campus \\ Chapecó, Rodovia SC 484, Km 02, Fronteira Sul, CEP 89815-899 Chapecó, SC, Brazil. E-mail: siumar.tironi@gmail.com
}

\begin{abstract}
The objective of this work was to evaluate the density and composition of the soil weed seed bank when bean, corn, and soybean are cultivated in the no-tillage system (NTS) in rotation with winter cover crop species and in the conventional tillage system (CTS). The experiment was installed in a complete randomized block design with three replicates. The evaluation of the seed bank was performed on soil samples $(0-10$ and $10-20 \mathrm{~cm}$ ) in four points of each experimental unit, at 15,30,60, and 90 days of cultivation. Bean, corn, and soybean crops were sown in the NTS with different soil cover crops in rotation, as well as in the CTS. The NTS provided a more dense and abundant soil seed bank of the species Gnaphalium spicatum and Oxalis corniculata when corn, soybean, and bean were cultivated. The species Lolium multiflorum showed lower density and less seeds in the soil seed bank when the NTS was adopted. The use of the winter cover crops black oat and cow vetch, cultivated individually or in consortium, resulted in a lower density of weed species, especially of L. multiflorum. The NTS provides a lower density of weed species in the soil seed bank than the CTS.
\end{abstract}

Index terms: Avena strigosa, Raphanus sativus, Vicia sativa, conventional tillage system, no-tillage system.

\section{Sistemas de manejo do solo e sua influência no banco de sementes de plantas daninhas}

Resumo - O objetivo deste trabalho foi avaliar a densidade e a composição do banco de sementes de plantas daninhas do solo ao se cultivar feijão, milho e soja no sistema plantio direto (SPD), em rotação com espécies de cobertura de inverno, e no sistema plantio convencional (SPC). O experimento foi instalado em campo, em delineamento de blocos ao acaso, com três repetições. A contagem do banco de sementes foi realizada em amostras de solo (0-10 e 10-20 cm) em quatro pontos de cada unidade experimental, aos 15, 30, 60 e 90 dias de cultivo. As culturas de feijão, milho e soja foram semeadas no SPD com diferentes coberturas vegetais do solo em rotação, bem como no SPC. O SPD proporcionou banco de sementes do solo com maior densidade e abundância das espécies Gnaphalium spicatum e Oxalis corniculata com o cultivo de milho, soja e feijão. A espécie Lolium multiflorum teve menor densidade e menos sementes no banco do solo ao se adotar o SPD. $\mathrm{O}$ uso das coberturas de inverno aveia-preta e ervilhaca, em cultivo isolado ou em consórcio, proporcionou menor densidade de espécies de plantas daninhas, em especial de L. multiflorum. O SPD proporciona menor densidade de espécies de plantas daninhas no banco de sementes do solo que o SPC.

Termos para indexação: Avena strigosa, Raphanus sativus, Vicia sativa, sistema plantio convencional, sistema plantio direto.

\section{Introduction}

The no-tillage system (NTS) was introduced in Brazil in the late 1960s and mid-1970s and, since then, has grown steadily compared with the conventional tillage system (CTS) (Silva et al., 2009). Currently, the NTS has been almost entirely adopted in the country in crops such as bean, corn, and soybean
(Acompanhamento..., 2017; FEBRAPDP, 2017). This technique offers innumerable advantages for the agricultural sector and the environment, mainly due to the reduction of soil losses caused by erosion, to the lower burning of organic matter with reduced $\mathrm{CO}_{2}$ release, and to pest control, among others (Silva et al., 2009; Buchanan et al., 2016; Scherner et al., 2016). 
One of the basic premises of the NTS is the maintenance of plant cover on the soil, which can contribute significantly to the reduction of the weed seed bank, either by the biomass produced or by the allelopathic potential of these species (Jabran et al., 2015; Buchanan et al., 2016). Changes in the ecosystem, including crop rotation/succession, soil rotation, and fertilizer management, also alter the seed bank of the soil, which is closely related to its disturbance levels (Chauhan et al., 2006; Hosseini et al., 2014).

It should be noted that several species show suppressive effects on weed germination. This is the case of corn, teosinte, sesbania, cowage, rattlepod, and millet as summer cover crops, and of radish, lupine, ryegrass, cow vetch, and oat as winter cover crops (Rizzardi \& Silva 2006; Monquero et al., 2009; Lamego et al., 2015). Buchanan et al. (2016) assessed the cultivation of barley and clover alone or in consortium in the winter period for four years and concluded that there was a $50 \%$ reduction in the soil weed seed bank, mainly due to the physical or allelopathic effects of the biomass produced.

Conventional soil preparation and the burning of vegetal residues are practices that favor the weed seed bank to the detriment of native species (Ikeda et al., 2008). In the NTS, the number of weed seeds in the soil is considered high, but the percentage of seeds that may germinate and become competitive may be considered low (Gomes Jr. \& Christoffoleti, 2008). This happens because, in the NTS, where weed seeds are concentrated on soil surface, there is a decrease in the seed bank due to induced germination, loss of viability, predation, and parasitism (Monquero \& Christoffoleti, 2005).

According to Chauhan et al. (2006), the deterioration of seeds under the NTS was higher when compared with minimum tillage. The population of Setaria faberi R.A.W.Herrm., for example, was concentrated in the top 2.5-cm layer of the soil under minimum tillage or NTS. When evaluating a system without soil inversion for 11 years, Scherner et al. (2016) found that most of the seeds were concentrated in the $0-5$ and $5-10-\mathrm{cm}$ layers. These same authors also pointed out that soil inversion becomes interesting if one of these species becomes problematic in the crops, that is, if it acquires resistance to a certain herbicide.

The NTS may favor some weed genera, such as Digitaria, whereas conventional preparation may favor species of the genus Cyperus or even other species that reproduce in a vegetative way (Silva et al., 2005). For this reason, it is difficult to obtain information about the effect of the rotation of corn, soybean, and bean crops with winter cover crops in these systems, in order to identify which is the most appropriate management to reduce or even eliminate the weed seed banks. This is important because the decrease in the soil weed seed bank favors the reduction of herbicide use and, consequently, the environmental impacts caused by the rotation of corn, soybean, and bean crops.

The objective of this work was to evaluate the density and composition of the soil weed seed bank when bean, corn, and soybean are cultivated in the NTS in rotation with winter cover crop species and in the CTS.

\section{Materials and Methods}

The experiment was established in the field in the 2013/2014 and 2014/2015 crop seasons, in the municipality of Quatro Irmãos, in the state of Rio Grande do Sul, Brazil (274ㄴ'42,95"S, 52²5'51,26"W, at $581 \mathrm{~m}$ of altitude). The soil of the region is classified as a Cambissolo Háplico Ta eutrófico (Santos et al., 2013), i.e., a Typic Dystrudepts, and the climate is characterized as Cfa, humid subtropical, according to Köppen's classification. Average monthly rainfall during the experimental period was 232 and $211 \mathrm{~mm}$ for the first and second crop seasons, respectively.

The experimental design was a randomized complete block with three replicates. The treatments tested consisted of the NTS and CTS with different crop rotations (Table 1). The experimental area, predominantly composed of ryegrass (Lolium multiflorum Lam.), was previously cultivated with two consecutive soybean [Glycine $\max$ (L.) Merr.] cultivars in summer and was used for animal grazing in winter (fallow). The cultivation system of the area in the last ten years was no-tillage, without soil inversion. Weeds were controlled with herbicides: glyphosate in summer and metsulfuron-methyl three years before the beginning of the experiment for the management of flaxleaf fleabane [Conyza bonariensis (L.) Cronquist].

Prior to the establishment of each summer crop bean (Phaseolus vulgaris L.), corn (Zea mays L.), and soybean -, soil cover crops were planted individually or in consortium. In the area without cover crops (fallow), the soil was managed in the CTS, with soil 
tillage through plowing and harrowing. Later, the bean, corn, and soybean crops were sown. The winter and summer cover crops were established in the NTS according to the principles of minimal soil disturbance, maintenance of crop residues on soil surface, and crop rotation.

The desiccation of the vegetation cover in the different cultivation systems was performed using 1.08 $\mathrm{kg} \mathrm{ha}^{-1}$ acid equivalent of the herbicide glyphosate, together with $0.22 \mathrm{~kg} \mathrm{ha}^{-1}$ sethoxydim. The plots consisted of six $10-\mathrm{m}$ long lines, spaced at $0.47 \mathrm{~m}$, totaling an area of $28.2 \mathrm{~m}^{2}$.

The plant densities adopted for the winter soil cover crops were as follows: 130 plants per square meter for black oat (Avena strigosa Schreb.), 100 plants per square meter for radish (Raphanus sativus L.), 170 plants per square meter for cow vetch (Vicia sativa $\mathrm{L}$.), $90+50$ plants per square meter for black oat + cow vetch, $90+30$ plants per square meter for black oat + radish, and $170+35$ plants per square meter for cow vetch + radish. Sowing was performed with the aid of a seeder/fertilizer, using $200 \mathrm{~kg} \mathrm{ha}^{-1}$ of the formula $\mathrm{N}-\mathrm{P}_{2} \mathrm{O}_{5}-\mathrm{K}_{2} \mathrm{O}$ (08-24-12) and $45 \mathrm{~kg} \mathrm{ha}^{-1}$ nitrogen broadcasted in the form of urea $(45 \% \mathrm{~N})$. For summer crops, seedling density per square meter was: 30 for 'BMX Alvo' soybean, 21 for 'BRS Campeiro' bean, and 6 for the corn hybrids AG 8041 PRO in the first year and SX 7331 VIP in the second one.

Sowing of summer crops was also carried out with the aid of a seeder/fertilizer, using $350 \mathrm{~kg} \mathrm{ha}^{-1}$ of the formula $\mathrm{N}-\mathrm{P}_{2} \mathrm{O}_{5}-\mathrm{K}_{2} \mathrm{O}(05-30-15)$ for the bean, corn, and soybean crops in the two crop seasons. Broadcast fertilization consisted of 45 and $122 \mathrm{~kg} \mathrm{ha}^{-1} \mathrm{~N}$ appliet to bean and corn, respectively.
Weed control in the bean crop was performed with the aid of the commercial mixture of the herbicides fluazifop-p-butyl + fomesafen at the doses of $0.25+$ $0.25 \mathrm{~kg} \mathrm{ha}^{-1}$. The commercial mixture of the herbicides atrazine + simazine at the doses of $1.25+1.25 \mathrm{~kg} \mathrm{ha}^{-1}$ was used for the corn crop, while glyphosate at the dose of $1.08 \mathrm{~kg} \mathrm{ha}^{-1}$ a.i. was applied to the soybean crop.

After harvesting of the summer crops, the soil was collected at the center of each experimental unit in April 2013, 2014, and 2015. In 2013, the seed bank was evaluated to determine the weed species present before the establishment of the experiment. With the aid of a spade and a cutting blade, four subsamples of $1 \mathrm{~kg}$ soil were collected from the $0-10$ and $10-20-\mathrm{cm}$ layers, in each experimental unit, by first homogenizing and then removing the soil, according to Monquero \& Christoffoleti (2005). The subsamples were stored in $10 \times 36 \times 41-\mathrm{cm}$ plastic trays, placed in a greenhouse, and irrigated once or several times a day to maintain $80 \%$ field capacity, allowing the germination of the weed seeds present in the soil samples.

Emerged seedlings were identified, counted, and removed from the tray. Evaluations were performed at 15, 30, 60, and 90 days after the greenhouse test, following the methodology proposed by FroudWilliams et al. (1983). Seedlings that could not be identified to the species level were transplanted to 8 -L plastic pots for future identification in the reproductive stage.

The obtained data were analyzed for homoscedasticity and normality in order to test for normal distribution, and were subsequently subjected to the analysis of variance by the F-test. The density and relative density of each species of weed present

Table 1. Management systems and crop rotation used in the first and second crop seasons.

\begin{tabular}{|c|c|c|c|c|}
\hline \multirow[t]{2}{*}{ Management $t^{(1)}$} & \multicolumn{2}{|c|}{ 2013/2014 crop season } & \multicolumn{2}{|c|}{ 2014/2015 crop season } \\
\hline & Winter & Summer & Winter & Summer \\
\hline NTS1 & Black oat & Soybean & Radish & Soybean \\
\hline NTS2 & Black oat + radish & Bean & Black oat & Corn \\
\hline NTS3 & Black oat + cow vetch & Soybean & Cow vetch & Corn \\
\hline NTS4 & Radish + cow vetch & Corn & Black oat + Radish & Bean \\
\hline NTS5 & Radish & Bean & Radish + cow vetch & Bean \\
\hline NTS6 & Cow vetch & Corn & Black oat + cow vetch & Soybean \\
\hline CTS1 & Fallow & Corn & Fallow & Soybean \\
\hline CTS 2 & Fallow & Bean & Fallow & Corn \\
\hline CTS 3 & Fallow & Soybean & Fallow & Bean \\
\hline
\end{tabular}

(1)NTS, no-tillage system with cover crop rotation; and CTS, conventional tillage system with winter fallow. 
in the different treatments, as well as the total number of emerged seedlings, were determined. For the first variable, a descriptive analysis was performed, and for the second one, the averages were compared by Tukey's test, at 5\% probability. The data were analyzed with the aid of the statistical software Assistat (Silva, 2015).

\section{Results and Discussion}

During the three evaluations carried out, the presence of 7 families and 12 weed species was observed (Table 2). The family Asteraceae was represented by the largest number of species (4), followed by the families Euphorbiaceae and Poaceae, both with 2 species each. Since the studied area had more than 20 years of agricultural activity, with grain and pasture production, the weed seed bank was diversified, even though it had been cultivated in the NTS over the past ten years. It should be highlighted that the size of the weed seed bank is greater in agricultural than in nonagricultural areas with a low environmental impact, which can be explained by the strategy of plants to produce more seeds in environments with greater soil disturbance (Monquero \& Christoffoleti, 2005).

The weed seed bank of the experimental area was evaluated, and six species were found: L. multiflorum, R. sativus, Bidens pilosa L., Stachys arvensis L., Oxalis corniculata L., and Digitaria ciliaris (Retz.) Koeler. The species that presented the highest seed density was O. corniculata, accounting for $63.31 \%$ of the total seed density, followed by L. multiflorum (Table 3), which stands out in the Southern states of

Table 2. Distribution by family and species of the weeds collected in the different cropping systems and crops.

\begin{tabular}{lcc}
\hline Family & Species & Common name \\
\hline Asteraceae & Bidens pilosa & Beggarticks \\
& Conyza bonariensis & Horseweed \\
& Gnaphalium spicatum & Cudweed \\
Sonchus oleraceus & Sow thistle \\
\hline Brassicaceae & Raphanus sativus & Radish \\
\hline Caryophyllaceae & Agrostemma githago & Corncockle \\
\hline Euphorbiaceae & Euphorbia heterophylla & Wild poinsettia \\
\hline Lamiaceae & Chamaesyce hirta & Pillpod sandmat \\
\hline Oxalidaceae & Stachys arvensis & Staggerweed \\
\hline Poaceae & Oxalis corniculata & Creeping woodsorrel \\
\hline
\end{tabular}

Brazil as it is adapted to low temperature conditions in the winter season and causes damages to wheat (Triticum aestivum L.), barley (Hordeum vulgare L.), canola (Brassica napus L.), triticale ( $\times$ Triticosecale Wittm.), and rye (Secale cereale L.) crops (Lamego et al., 2013).

The number of seedlings emerged in the 0 to $10-\mathrm{cm}$ layer was higher than that of the 10 to $20-\mathrm{cm}$ layer, most probably because of the low soil disturbance in the NTS in the years before the evaluation. Seedling emergence was $490 \%$ higher in the 0 to $10-\mathrm{cm}$ layer than in the 10 to $20-\mathrm{cm}$ one (Table 4). The longer the cultivation time without soil inversion, the higher was the seed concentration in the layers from 0 to 5 and from 5 to $10 \mathrm{~cm}$ (Scherner et al., 2016).

In the first evaluation year (2013/2014 crop year), the weed $S$. arvensis showed the highest relative seed density in the NTS with the different winter cover crops and in the CTS (Table 5). The species O. corniculata and G. spicatum also showed considerable densities, but decreased drastically under the CTS, possibly due to the incorporation of seeds or to the exposure of seeds to germination or predation conditions (Table 5). These results are in alignment with those found by Isaac \& Guimarães (2008), who observed variations in the species in the weed seed bank under the NTS and CTS.

Table 3. Relative density (\%) of weed species prior to the implementation of the soil tillage systems.

\begin{tabular}{lc}
\hline Species & Relative density (\%) \\
\hline Lolium multiflorum & 16.54 \\
Raphanus sativus & 1.03 \\
Bidens pilosa & 7.49 \\
Stachys arvensis & 10.59 \\
Oxalis corniculata & 63.31 \\
Digitaria ciliaris & 1.03 \\
\hline Total of seedlings & 122 \\
\hline
\end{tabular}

Table 4. Number of seedlings emerged in the 0 to 10 and 10 to $20-\mathrm{cm}$ soil layers and total number of seedlings prior to the experiment ${ }^{(1)}$.

\begin{tabular}{lc}
\hline Soil layers $(\mathrm{cm})$ & Number of seedlings (per kg of soil) \\
\hline 0 to 10 & $101.33 \mathrm{a}$ \\
10 to 20 & $20.67 \mathrm{~b}$ \\
\hline Total of seedlings & 122.00 \\
\hline Coefficient of variation (\%) & 5.72 \\
\hline (1) Means followed by equal letters, within the column, do not differ by the \\
t-test, at 5\% probability.
\end{tabular}


There was a decrease in the L. multiflorum seed bank with the establishment of the NTS, independently of the summer crop, when compared with the CTS, i.e., winter fallow (Table 5); this result can be explained by the fact that soil residues from the soil cover crops adversely affect weed germination and development. However, in the area with the CTS, the species L. multiflorum was predominant, producing high amounts of seeds to replenish the seed bank. In the NTS, there was an increase in the seed bank of the species C. bonariensis, since the control of this species is facilitated in revolved soil. Therefore, the weed management in the area affects the composition and size of the soil seed bank (Monquero \& Christoffoleti, 2005).

The total average number of seedlings per kilogram of soil was 227.2 in the CTS and 71.8 in the NTS, indicating a reduction of $68.4 \%$ (Table 5). This is attributed to the lower infestation of weeds and, consequently, the lower seed production in areas with soil cover, as well as to the low soil disturbance, which decreases the long-term persistence of seeds in the soil and also causes the deterioration of seeds in the superficial soil layers in the NTS (Chauhan et al., 2006; Murphy et al., 2006).

Regarding the number of emerged seedlings in the different layers, the largest populations were observed in the CTS in the samples from the 0 to $10-\mathrm{cm}$ layer (Tables 1 and 6). Of the treatments, only NTS5 did not differ from CTS2, most probably because the winter cover crop had a low $\mathrm{C} / \mathrm{N}$ ratio, which facilitated the decomposition of the residues, allowing a greater establishment of weeds that will reflect in seed production if the control methods are not efficient. The other treatments in the NTS resulted in statistically lower values than those in the CTS, which was also observed in the 10 to $20-\mathrm{cm}$ layer. When the layers were compared with each other, in $66 \%$ of the treatments in the NTS, the seed content was higher in the 0 to $10-\mathrm{cm}$ layer, which is a tendency in cultivated soils without soil inversion due to the greater presence of weed seeds in the layers from 0 to 5 and 5 to $10 \mathrm{~cm}$, as previously reported by Scherner et al. (2016).

In the CTS, there were differences between the layers only when corn was cultivated (Table 6). It is important to emphasize that, in this system, soil disturbance results in a homogeneous distribution of the seeds in the soil profile (Chauhan et al., 2006; Scherner et al., 2016), which promotes the prolongation of the "life span" of the soil seed bank, since the emergence flow is not the same as in the NTS.

The total number of emerged seedlings was lower in all treatments in the NTS, when compared with the CTS. Seedling emergence was on average $216 \%$ higher in the CTS than in the NTS (Table 6). The weed seed bank in the soil is dependent on its disturbance levels since inversion, fertilization, and crop rotation contribute to seed population variability in the soil; these disturbances also affect different soil layers (Chauhan et al., 2006; Hosseini et al., 2014). Moreover, the NTS depleted the weed seed bank, regardless of the crop sown in summer, the soil cover crops established in winter, and/or the two soils layers collected.

Table 5. Relative density (\%) of the weed species in the first evaluation (2013/2014 crop season) in the no-tillage system (NTS) and the conventional tillage system (CTS).

\begin{tabular}{|c|c|c|c|c|c|c|c|c|c|}
\hline Species & NTS1 & NTS2 & NTS3 & NTS4 & NTS5 & NTS6 & CTS1 & CTS2 & CTS3 \\
\hline Lolium multiflorum & 2.59 & 10.55 & 7.00 & 3.16 & 1.40 & 6.94 & 19.92 & 24.40 & 56.56 \\
\hline Raphanus sativus & 5.17 & 0.55 & 0.50 & 0.00 & 2.80 & 1.16 & 0.00 & 0.00 & 0.16 \\
\hline Bidens pilosa & 0.00 & 0.00 & 0.50 & 0.63 & 0.00 & 1.73 & 0.00 & 0.22 & 0.00 \\
\hline Stachys arvensis & 44.39 & 47.22 & 56.50 & 40.51 & 68.69 & 68.79 & 73.83 & 70.11 & 41.82 \\
\hline Oxalis corniculata & 12.50 & 15.00 & 9.50 & 11.39 & 7.94 & 4.05 & 1.76 & 2.20 & 0.97 \\
\hline Digitaria ciliaris & 0.00 & 0.00 & 1.00 & 20.25 & 0.00 & 0.00 & 0.20 & 0.00 & 0.16 \\
\hline Gnaphalium spicatum & 17.67 & 14.44 & 6.50 & 14.55 & 8.41 & 10.40 & 4.30 & 2.42 & 0.00 \\
\hline Agrostemma githago & 0.86 & 0.00 & 0.50 & 0.00 & 1.87 & 0.00 & 0.00 & 0.44 & 0.16 \\
\hline Chamaesyce hirta & 4.31 & 5.00 & 5.50 & 1.26 & 5.14 & 0.00 & 0.00 & 0.22 & 0.00 \\
\hline Euphorbia heterophylla & 0.86 & 0.55 & 0.50 & 0.00 & 0.00 & 0.00 & 0.00 & 0.00 & 0.00 \\
\hline Conyza bonariensis & 11.63 & 6.67 & 12.00 & 8.22 & 3.74 & 6.94 & 0.00 & 0.00 & 0.16 \\
\hline Number of seedlings & 75.50 & 47.50 & 68.00 & 73.50 & 91.50 & 75.00 & 214.50 & 192.00 & 275.00 \\
\hline
\end{tabular}


In the second evaluation (2014/2015 crop year), $S$. arvensis and $O$. corniculata were the species with the highest densities in the NTS treatments (Table 7). In the CTS, independently of the summer crop, the weed with the highest density was L. multiflorum, as the area remained in fallow; this species causes losses in the quality and quantity of wheat (Lamego et al., 2013), barley, rye, triticale, and canola grains in Southern Brazil, requiring early control to avoid competition with these crops. Soil management using cover crops in the winter season substantially reduces the ryegrass seed bank, reducing herbicide expenditures during desiccation or when cleaning winter crops.

The species G. spicatum and R. sativus were found in the NTS and in the CTS, but at low densities. The species B. pilosa, E. heterophylla, and S. oleraceus were identified in three treatments: CTS, NTS2, and CTS3, respectively (Table 7).

There was no statistical difference between the number of seedlings emerged in each soil layer and species. However, in relation to the response variable total number of seedlings, CTS1 maintained in winter fallow and seeded with soybean in summer showed the highest number of seeds in the soil (Table 7), indicating that the management adopted for each crop can change the amount of weed seeds present in the soil. This happens due to the different management methods used for each crop, directly affecting the soil seed bank. Murphy et al. (2006) observed that the seed bank decreased drastically after six crop seasons of corn, soybean, and wheat under no-tillage systems, and that yield was not affected by the cultivation method. According to these same authors, minimum soil disturbance with crop rotation reduces the density of weeds from 41,000 to 8,000 seeds per square meter and decreases the costs with their control.

Among the treatments in the NTS, radish + soybean cover crops planted in succession presented the largest seed bank (Table 8). Radish can provide a faster establishment of weeds as it produces less residues to

Table 6. Number of seedlings (per kg of soil) emerged in the 0 to 10 and 10 to 20 -cm soil layers, as well as total number of seedlings in the no-tillage system (NTS) and the conventional tillage system (CTS) in the first evaluation (2013/2014 crop season $)^{(1)}$.

\begin{tabular}{lccc}
\hline Management & 0 to $10 \mathrm{~cm}$ & 10 to $20 \mathrm{~cm}$ & Number of seedlings (per kg of soil) \\
\hline NTS1 & $51.67 \mathrm{cA}$ & $23.83 \mathrm{cB}$ & $75.50 \mathrm{c}$ \\
NTS2 & $36.50 \mathrm{cA}$ & $11.00 \mathrm{cB}$ & $47.50 \mathrm{c}$ \\
NTS3 & $41.67 \mathrm{cA}$ & $26.33 \mathrm{cA}$ & $68.00 \mathrm{c}$ \\
NTS4 & $49.00 \mathrm{cA}$ & $24.50 \mathrm{cB}$ & $73.50 \mathrm{c}$ \\
NTS5 & $69.00 \mathrm{bcA}$ & $22.50 \mathrm{cB}$ & $91.50 \mathrm{c}$ \\
NTS6 & $45.50 \mathrm{cA}$ & $29.50 \mathrm{cA}$ & $75.00 \mathrm{c}$ \\
CTS1 & $146.50 \mathrm{aA}$ & $68.00 \mathrm{bB}$ & $214.50 \mathrm{ab}$ \\
CTS2 & $93.50 \mathrm{bA}$ & $98.50 \mathrm{bA}$ & $192.00 \mathrm{~b}$ \\
CTS3 & $134.33 \mathrm{aA}$ & $140.67 \mathrm{aA}$ & $275.00 \mathrm{a}$ \\
\hline CV $(\%)$ & & 17.76
\end{tabular}

${ }^{(1)}$ Values followed by equal letters, lowercase in the columns and uppercase in the rows, do not differ by Tukey's test, at $5 \%$ probability.

Table 7. Relative density (\%) of weed species in the second evaluation (2014/2015 crop season) in the no-tillage system (NTS) and the conventional tillage system (CTS).

\begin{tabular}{|c|c|c|c|c|c|c|c|c|c|}
\hline Species & NTS1 & NTS2 & NTS3 & NTS4 & NTS5 & NTS6 & CTS1 & CTS2 & CTS3 \\
\hline Lolium multiflorum & 0.41 & 0.00 & 5.26 & 19.35 & 2.25 & 3.08 & 44.07 & 76.81 & 45.64 \\
\hline Raphanus sativus & 2.07 & 1.94 & 0.00 & 0.00 & 2.25 & 3.08 & 7.31 & 4.49 & 5.03 \\
\hline Bidens pilosa & 0.00 & 0.00 & 0.00 & 0.00 & 0.00 & 0.00 & 0.20 & 0.25 & 0.34 \\
\hline Stachys arvensis & 69.83 & 49.51 & 38.95 & 55.91 & 65.17 & 63.08 & 43.68 & 13.97 & 43.29 \\
\hline Oxalis corniculata & 22.31 & 38.83 & 52.63 & 22.58 & 29.21 & 23.08 & 1.78 & 3.99 & 4.36 \\
\hline Gnaphalium spicatum & 5.37 & 8.74 & 3.16 & 2.15 & 1.12 & 7.69 & 2.96 & 0.50 & 0.00 \\
\hline Euphorbia heterophylla & 0.00 & 0.97 & 0.00 & 0.00 & 0.00 & 0.00 & 0.00 & 0.00 & 0.00 \\
\hline Sonchus oleraceus & 0.00 & 0.00 & 0.00 & 0.00 & 0.00 & 0.00 & 0.00 & 0.00 & 1.34 \\
\hline Number of seedlings & 80.66 & 29.50 & 20.50 & 44.50 & 29.67 & 33.50 & 205.67 & 122.50 & 99.33 \\
\hline
\end{tabular}


Table 8. Number of seedlings (per $\mathrm{kg}$ of soil) emerged in the 0 to 10 and 10 to $20-\mathrm{cm}$ soil layers, as well as total number of seedlings in the no-tillage system (NTS) and the conventional tillage system (CTS) in the second evaluation $\left(2014 / 2015\right.$ crop season) ${ }^{(1)}$.

\begin{tabular}{lccc}
\hline Management & 0 to $10 \mathrm{~cm}$ & 10 to $20 \mathrm{~cm}$ & $\begin{array}{c}\text { Number of seedlings } \\
\text { (per kg of soil) }\end{array}$ \\
\hline NTS1 & $45.00^{\text {ns }}$ & $35.67^{\text {ns }}$ & $80.66 \mathrm{bc}$ \\
NTS2 & 15.50 & 14.00 & $29.50 \mathrm{~d}$ \\
NTS3 & 9.50 & 11.00 & $20.50 \mathrm{~d}$ \\
NTS4 & 35.50 & 9.00 & $44.50 \mathrm{~cd}$ \\
NTS5 & 24.33 & 5.33 & $29.67 \mathrm{~d}$ \\
NTS6 & 27.00 & 6.50 & $33.50 \mathrm{~cd}$ \\
CTS1 & 128.33 & 77.33 & $205.67 \mathrm{a}$ \\
CTS2 & 89.50 & 33.00 & $122.50 \mathrm{~b}$ \\
CTS3 & 68.50 & 30.83 & $99.33 \mathrm{~b}$ \\
\hline CV $(\%)$ & - & - & 22.96
\end{tabular}

(1)Means followed by equal letters, in the columns, do not differ by Tukey's test, at $5 \%$ probability. ${ }^{\text {ns }}$ Nonsignificant. $\mathrm{CV}$, coefficient of variation.

cover the soil compared with black oat (Valicheski et al., 2012). In addition, radish has a low $\mathrm{C} / \mathrm{N}$ ratio, which favors the emergence of weeds in comparison with other winter coverages; therefore, the recommendation of applying weed control methods sooner (Rizzardi \& Silva, 2006).

\section{Conclusions}

1. The no-tillage system (NTS) provides a more dense and abundant seed bank of the species Gnaphalium spicatum and Oxalis corniculata when corn (Zea mays), soybean (Glycine max), and bean (Phaseolus vulgaris) are cultivated.

2. Lolium multiflorum shows lower density and less seeds in the soil seed bank when the NTS is adopted for the production of corn, soybean, and bean.

3. The use of the winter cover crops black oat (Avena strigosa) and cow vetch (Vicia sativa), cultivated individually or in consortium, results in a lower density of weed species, especially of L. multiflorum.

4. The NTS provides a lower density and number of seeds of weed species in the soil seed bank than the conventional tillage system.

\section{Acknowledgments}

To Conselho Nacional de Desenvolvimento Científico e Tecnológico (CNPq), to Fundação de Amparo à Pesquisa do Estado do Rio Grande do Sul
(Fapergs), and to Financiadora de Estudos e Projetos (Finep), for financial support and for grants.

\section{References}

ACOMPANHAMENTO DA SAFRA BRASILEIRA [DE] GRÃOS: safra 2016/17: quarto levantamento, v.4, n.4, jan. 2017. Available at: <http://www.conab.gov.br/OlalaCMS/uploads/ arquivos/17_01_11_11_30_39_boletim_graos_janeiro_2017.pdf $>$. Accessed on: Jan. 222017.

BUCHANAN, A.L.; KOLB; L.N.; HOOKS, C.R.R. Can winter cover crops influence weed density and diversity in a reduced tillage vegetable system? Crop Protection, v.90, p.9-16, 2016. DOI: 10.1016/j.cropro.2016.08.006.

CHAUHAN, B.S.; GILL, G.; PRESTON, C. Influence of tillage systems on vertical distribution, seedling recruitment and persistence of rigid ryegrass (Lolium rigidum) seed bank. Weed Science, v.54, p.669-676, 2006. DOI: 10.1614/WS-05-184R.1.

FEBRAPDP. Federação Brasileira de Plantio Direto e Irrigado. Evolução área do sistema plantio direto no Brasil. Available at: $\quad<$ http://febrapdp.org.br/download/PD_Brasil_2013.jpg $>$. Accessed on: July 82017.

FROUD-WILLIAMS, R.J.; CHANCELLOR, R.J.; DRENNAN, D.S.H. Influence of cultivation regime upon buried weed seeds in arable cropping systems. Journal of Applied Ecology, v.20, p.199-208, 1983. DOI: 10.2307/2403386.

GOMES JR., F.G.; CHRISTOFFOLETI, P.J. Biologia e manejo de plantas daninhas em áreas de plantio direto. Planta Daninha, v.26, p.789-798, 2008. DOI: 10.1590/S0100-83582008000400010.

HOSSEINI, P.; KARIMI, H.; BABAEI, S.; MASHHADI, H.R.; OVEISI, M. Weed seed bank as affected by crop rotation and disturbance. Crop Protection, v.64, p.1-6, 2014. DOI: 10.1016/j. cropro.2014.05.022.

IKEDA, F.S.; MITJA, D.; VILELA, L.; SILVA, J.C.S. Banco de sementes em cerrado sensu stricto sob queimada e sistemas de cultivo. Pesquisa Agropecuária Brasileira, v.43, p.667-673, 2008. DOI: $10.1590 /$ S0100-204X2008000600001.

ISAAC, R.A.; GUIMARÃES, S.C. Banco de sementes e flora emergente de plantas daninhas. Planta Daninha, v.26, p.521-530, 2008. DOI: $10.1590 / \mathrm{S} 0100-83582008000300007$.

JABRAN, K.; MAHAJAN, G.; SARDANA, V.; CHAUHAN, B.S. Allelopathy for weed control in agricultural systems. Crop Protection, v.72, p.57-65, 2015. DOI: 10.1016/j.cropro.2015.03.004.

LAMEGO, F.P.; CARATTI, F.C.; REINEHR, M.; GALLON, M.; LUIS-SANTI, A.; BASSO, C.J. Potencial de supressão de plantas daninhas por plantas de cobertura de verão. Comunicata Scientiae, v.6, p.97-105, 2015.

LAMEGO, F.P.; RUCHEL, Q.; KASPARY, T.E.; GALLON, M.; BASSO, C.J.; SANTI, A.L. Habilidade competitiva de cultivares de trigo com plantas daninhas. Planta Daninha, v.31, p.521-531, 2013. DOI: $10.1590 / \mathrm{S} 0100-83582013000300004$.

MONQUERO, P.A.; AMARAL, L.R.; INÁCIO, E.M.; BRUNHARA, J.P.; BINHA, D.P.; SILVA, P.V.; SILVA, A.C. 
Efeito de adubos verdes na supressão de espécies de plantas daninhas. Planta Daninha, v.27, p.85-95, 2009. DOI: 10.1590/ S0100-83582009000100012.

MONQUERO, P.A.; CHRISTOFFOLETI, P.J. Banco de sementes de plantas daninhas e herbicidas como fator de seleção. Bragantia, v.64, p.203-209, 2005. DOI: 10.1590/S0006-87052005000200006.

MURPHY, S.D.; CLEMENTS, D.R.; BELAOUSSOFF, S.; KEVAN, P.G.; SWANTON, C.J. Promotion of weed species diversity and reduction of weed seedbanks with conservation tillage and crop rotation. Weed Science, v.54, p.69-77, 2006. DOI: 10.1614/WS-04-125R1.1.

RIZZARDI, M.A., SILVA, L.F. Influência das coberturas vegetais antecessoras de aveia-preta e nabo forrageiro na época de controle de plantas daninhas em milho. Planta Daninha, v.24, p.669-675, 2006. DOI: $10.1590 / \mathrm{S} 0100-83582006000400007$.

SANTOS, H.G. dos; JACOMINE, P.K.T.; ANJOS, L.H.C. dos; OLIVEIRA, V.A. de; LUMBRERAS, J.F.; COELHO, M.R.; ALMEIDA, J.A. de; CUNHA, T.J.F.; OLIVEIRA, J.B. de. Sistema brasileiro de classificação de solos. 3.ed. rev. e ampl. Brasília: Embrapa, 2013. 353p.

SCHERNER, A.; MELANDER, B.; KUDSK, P. Vertical distribution and composition of weed seeds within the plough layer after eleven years of contrasting crop rotation and tillage schemes. Soil and Tillage Research, v.161, p.135-142, 2016. DOI: 10.1016/j.still.2016.04.005.

SILVA, A.A. da; GALON, L.; FERREIRA, F.A.; TIRONI, S.P.; FERREIRA, E.A.; SILVA, A.F. da; ASPIAZÚ, I.; AGNES, E.L. Sistema de plantio direto na palhada e seu impacto na agricultura brasileira. Revista Ceres, v.56, p.496-506, 2009.

SILVA, C.S.W.; SOUZA, C.M. de; SOUZA, B.A. de; FAGUNDES, J.L.; FALLEIRO, R. de M.; SILVA, A.A. da; SEDIYAMA, C.S. Efeitos dos sistemas de preparo do solo na comunidade de plantas daninhas no milho. Revista Ceres, v.52, p.555-566, 2005.

SILVA, F. de A.S. e. ASSISTAT - Assistência Estatística: [versão 7.7 beta]. Campina Grande: Universidade Federal de Campina Grande, 2015. Available at: <http://www.assistat.com/>. Accessed on: Nov. 202017.

VALICHESKI, R.R.; GROSSKLAUS, F.; STÜRMER, S.L.K.; TRAMONTIN, A.L.; BAADE, E.S.A.S. Desenvolvimento de plantas de cobertura e produtividade da soja conforme atributos físicos em solo compactado. Revista Brasileira de Engenharia Agrícola e Ambiental, v.16, p.969-977, 2012. DOI: 10.1590/ S1415-43662012000900007.

Received on March 10, 2017 and accepted on August 8, 2017 